\title{
Physical violence at the workplace: Consequences on health and measures of prevention
}

\section{Violence physique sur le lieu de travail : conséquences sur la santé et mesures de prévention}

\author{
G. Steffgen \\ Research Unit INSIDE, axis AASC, université du Luxembourg, Campus Walferdange, bureau 1.05, bâtiment XII, \\ route de Diekirch, 7201 Walferdange, Luxembourg
}

\begin{abstract}
Based on definitions and theoretical models of physical violence at the workplace, this paper presents scientific knowledge and working hypotheses regarding both, the causes and effects of physical violence on health, and pertinent preventive measures of intervention to be taken by enterprises. Four groups of determinants of violence are presented and discussed: determinants relative to the structure and the culture of the enterprise; the aggressor; the victim; and the socio-cultural environment. The theoretical model by Baron and Neumann [Public Admin Q 21 (1998) 446-64] is used to explain the complex origin of violent behavior at work based on these determinants. Moreover, the various and multiple consequences of a violent act are examined. In addition to the direct effects of such an act on the social, organizational and individual level, the indirect effects are also taken into consideration. In this analytical context, health problems are more particularly underlined, such as the psychological trauma suffered by victims of a violent act. Finally, two different areas of intervention will be distinguished: interventions on the physical environment and interventions on the level of company management or an organizational group which aims at changing the behavior of the members of the organization. Different scientific evaluations of action programs to reduce violent acts are presented. In conclusion, this paper calls for further research on physical violence in the workplace.
\end{abstract}

(C) 2008 Elsevier Masson SAS. All rights reserved.

\section{Résumé}

En se basant sur des définitions scientifiques et des modèles théoriques de la violence physique sur le lieu de travail, l'article présente les savoirs scientifiques et les hypothèses de référence quant aux causes, quant aux effets sur la santé et quant aux mesures d'intervention préventive pertinentes à prendre à l'égard de la violence physique dans les entreprises. Quatre groupes de déterminants sont présentés et discutés : déterminants relatifs à la structure et culture de l'entreprise, à l'agresseur, à la victime et à l'environnement socioculturel. Le modèle théorique de Baron et Neumann, J.H. [Public Admin Q 21 (1998) 446-64] sert de modèle de référence pour expliquer la genèse complexe des comportements violents sur le lieu de travail à partir de ces déterminants. Par ailleurs, les conséquences variées et multiples de l'acte violent sont examinées. Mis à part les effets directs - au niveau social, organisationnel et individuel - d'un tel acte, les effets indirects sont également à prendre en considération. Dans ce contexte d'analyse, les problèmes de santé sont plus particulièrement mis en exergue, comme, par example, le traumatisme psychique subi par les victimes d'un acte violent. Enfin, deux différents domaines d'intervention vont être distingués : les interventions sur l'environnement physique et les interventions auprès de la direction d'une entreprise ou d'une unité organisationnelle et qui ont pour objectif le changement du comportement des membres de l'organisation. Différentes évaluations scientifiques de programmes d'actions pour réduire les actes violents sont présentées. En conclusion de cet article, un appel à intensifier la recherche sur la violence physique sur le lieu de travail est lancé.

(c) 2008 Elsevier Masson SAS. All rights reserved.

Keywords: Physical violence; Occupational health; Theoretical models; Measures of intervention

Mots clés : Violence physique ; Santé au travail ; Modèles théoriques ; Mesures d'intervention

E-mail address: georges.steffgen@uni.lu. 
It has become common to hear media reports of physical violence - extreme for the most part - at the workplace: ticket inspectors who are attacked by passengers in trains; members of the medical staff who mistreat their patients; security guards who are wounded or killed during robberies; even teachers who are attacked by students (Steffgen, 2004). In spite of the media coverage of physical violence in the workplace, the psychology of organizations has not made it a central subject of research.

It is well-known that in the professional environment (the workplace), psychological violence, in the form of verbal aggression, mobbing or (sexual) harassment, is recorded more often than are physical attacks (Chappell and DiMartino, 2000; Salminen, 1997; Tragno et al., 2007) and, therefore, it has attracted the scientific as well as the public interest more strongly in recent years (Rosen, 2001; Scezsny, 2004; Zapf, 2004). However, it has been established that numerous employees have been victims of physical attacks (Baron and Neumann, 1996) and that the frequency of acts of physical violence in the workplace is in progression (Flannery, 1996; Standing and Nicolini, 1997; Tobin, 2001; Warchol, 1998; Hoel et al., 2001).

This paper aims at making a review of the subject by offering a general overview of the research related to the prevalence of physical violence in the workplace, the causes of this localized violence, the consequences for the victims - particularly on the level of health - as well as proposed preventive measures.

\section{Definitions and forms}

In the social sciences, the notion of violence is defined in a different and a heterogeneous way. The notion is often reduced to that of an aggression and this designates the more extreme forms of violence. Violence, as an individual behavior, refers mainly to serious forms of physical aggression with an orientation towards dominance (Berkowitz, 1993; Bierhoff and Wagner, 1998).

Baron and Richardson (1994) consider aggression as all behavior whose goal is to inflict injury and to harm another human being, respectively, and/or offend him, while the latter clearly intends to avoid the injury and/or the offense.

According to Bornewasser (1998), the terms violence and aggression group different forms of action, which have in common a harmful effect on the victim and which falls within the sphere of normative prohibition. According to this author, the term aggression refers to impulsive aggression (having an emotional cause), while the term violence refers to functional aggression (without emotions, with an aim).

In addition to the distinction between impulsive and functional aggression originally offered by Feshbach (1964), other categorizations of the act which is physically or psychologically damaging have been proposed. Buss (1961), for example, distinguishes between physical and verbal aggression, active and passive aggression, and direct and indirect aggression (see also Tarquinio et al., 2004a). According to these authors, aggressions are acts which cause both psychological and physical prejudice to the victim as well as to the aggressor.
The distinction between structural and personal violence will be made below.

Galtung (1975) has defined the concept of "structural violence" as a prejudice caused by a social structure that has the particularity of preventing/hindering the development of (some) individual potentials of its members. This encompasses unjust/unequal treatment rooted in the norms, laws, rules, arrangements or customs that are specific to a social environment, an institution or an enterprise.

"Personal violence" includes the actions of individual actors that are directed towards other persons. It can be categorized as physical violence, psychological violence, sexual violence or violence by neglect or shortcomings. "Personal" physical violence can be directed at other individuals (homicide, murder, rape, sexual violence) or at oneself (self-mutilation, suicide) (Violanti, 1996).

According to Jenkins (1996), the notion of physical violence does not only include concrete cases of physical injury, but also cases in which threats of physical violence are made.

Regarding "physical" violence towards objects (damaging objects, vandalism), it must be distinguished from other forms of physical violence.

The definitions of (physical) violence at the workplace are again differentiated according to the sense (broad or literal) that is given to the notion of the workplace (Bulatao and VandenBos, 1996). Baron and Neumann (1998) propose restricting the notion of violence linked to the work station (workplace violence) to direct corporal attacks which occur in the workplace itself or within an organization. O'Leary-Kelly et al. (1996) distinguish between workplace aggression motivated by the existence of an organizational structure from workplace aggression explained by factors which are external to the organization such as conjugal or familial violence. Other less restrictive definitions, such as those by Hoad (1993) and Jenkins (1996), also include theft, familial violence and acts of terrorism as violence linked to the context of work.

A more recent definition offered by Howard (2001) considers that there is violence in the workplace if a prohibited behavior reduces the real and perceived security of the employee, supervisor or organization. This definition also includes violent events which occur outside of the workplace and working hours, insofar as the behaviors relate to motives linked to the job.

Depending on the link which exists between the aggressor and the organization, it is possible to distinguish four forms of violence in the workplace (Braverman, 1999; Peek-Asa et al., 2001). Type 1: the aggressor has no relationship to the enterprise and he uses the organization/the work station uniquely with the intention of committing a criminal act (for example, he attacks a taxi driver to rob him). Type 2: the aggressor is a client of the employee whom he threatens or even physically attacks (for example, a patient who attacks a nurse). Type 3: The aggressor is, or was, a co-worker of his victim whom he "punishes" in the workplace because, for example, he behaved unfairly to him. Type 4 includes all the situations in which a personal relationship between the aggressor and the victim exists without there being a relationship between the organization and the aggressor. 
This last category consists of "imported" familial violence in the workplace (Friedman et al., 1996).

\section{Prevalence of physical violence}

Estimating the rate of the number of acts of physical violence committed in the workplace is difficult since the definitions as well as the measuring methods differ in the studies done on this subject. Each study often has its own operationalization on physical violence in the workplace. Effectively, in the context of representative surveys, the items which were used have generally been constructed by the authors themselves. In other cases, lists of items or specific methods of measure are used regarding a defined professional setting/sector (Arnetz, 1998) or scales and normed aggression inventories (Buss and Perry, 1992; Hampel and Selg, 1998). Furthermore, "checklists" with the purpose of evaluating the danger of an exposition to violence in relation to a defined work station have also been used (LeBlanc and Kelloway, 2002). Finally, comparative estimations are difficult because the rate of the number of victims and aggressors varies according to the data sources that are used and the quality of the samples (biased statistics established by special interest groups; surveys that are representative or not; databases made up in various ways by research institutes).

For example, regarding the surveys that are systematically conducted in the United States, it seems clear that the results obtained differ (Bureau of Justice Statistics, Bureau of Labor Statistics, American National Crime Victimization Survey, National Institute for Occupational Safety and Health, U.S. Department of Labor Occupational Safety and Health Administration, California Occupational Safety and Health Administration, VandenBos and Bulatao, 1996). Based on a critical analysis of this data as well as on their research, Budd et al. (1996) estimate that, on the average, $2.5 \%$ of the employees have suffered physical violence and $7.4 \%$ have experienced threatening situations in the workplace in the USA (White, 1996). In all, two million employees would be victims of acts of violence and six million would be victims of threats per year in the USA (Barling, 1996).

The proportion of physical violence carried out by co-workers is quite low (Braverman, 1999). Effectively, the aggressors have no professional relationship with their victim in most of the cases (Peek-Asa et al., 1997; Hashemi and Webster, 1998).

The rate of homicides or murders committed in the workplace have attracted attention, in particular concerning the AngloAmerican area (Kraus, 1987; Bulatao and VandenBos, 1996). The statistics covering the period from 1980 to 1988 show that homicide is the third cause of death linked to the work station. It has even become the first cause of death in the workplace since 1993 (Castillo and Jenkins, 1994; Goodman et al., 1994; Lusk, 1992).

Here again, and in most cases, the aggressors are not coworkers but individuals who do not belong to the organization (Leonard and Sloboda, 1996). The majority of crimes which result in death are related to holdups or similar crimes (Baron and Neumann, 1996). The professions which are the most exposed include taxi drivers, policemen or secret service agents, gas station attendants and security guards. Moreover, men are more often victims of such violent acts compared to women (Jenkins, 1996; Kraus, 1987; Rutter and Hine, 2005).

The statistical data available for European countries is not very accurate either (Beale et al., 1996; Chappell and DiMartino, 2000). The European Foundation for the Improvement of Living and Working Conditions (2000) estimates that 4\% of the employees in the European Union are victims of physical violence carried out by individuals who do not belong to the organization and $2 \%$ are victims of physical violence carried out by co-workers. This data corresponds to the results of a study done by this foundation in 1996 and published in 1997 (Salminen, 1997). From a differential perspective, the influence of the field of work and the sex of the victim have been shown.

Although every enterprise or employee is potentially exposed to the risk of becoming a victim of violent acts (Collins et al., 1987), certain professions and workplaces are more particularly exposed. Hence, the employees in the health sector, in education and in industry represent groups at a higher risk as do employees in the law enforcement sector. These risk groups have been particularly studied by Flannery (1996), Baron and Neumann (1998) and Watson et al. (2001).

According to Hurrell et al. (1996), the employees in the health sector would be most often concerned by physical violence entailing injuries (Bulatao and VandenBos, 1996) and, furthermore, almost two-thirds of all the attacks reported (which did not result in the victim's death) took place in the health setting. Here too, differences exist in the different fields of health (Sullivan and Yuan, 1995). Poster and Ryan (1994) have shown that $26 \%$ of the nurses that were questioned had been threatened at least once by a patient with a weapon or a contaminated syringe (Lanza, 1996). In a representative sample of Swedish nurses, Arnetz et al. (1996) have shown that $29 \%$ of them have already been exposed to physical violence and $35 \%$ have been threatened with psychological violence. Similar results have been found by Whittington et al. (1996). As for psychologists, $39.9 \%$ of those interviewed by Guy et al. (1990) have indicated that they have already been attacked once by one of their patients.

Guterman et al. (1996) have interviewed American and Israeli social workers who have frequent professional contact with clients with case histories of violence. Twenty percent of the social workers indicated that they had already suffered physical violence or received threats at least once. Moreover, $6 \%$ of the American social workers and $1 \%$ of the Israeli social workers indicated that they had been confronted by sexual violence. Schulte et al. (1998) have shown that $12 \%$ of the social workers active in the field of public health had been threatened at least once with a weapon, that $4 \%$ had suffered physical violence and that $1 \%$ had been victims of rape (Jayaratne et al., 1996). Skarpaas and Hetle (1996) have reported that $20.9 \%$ of the Norwegian social workers had already been victims of physical violence or had been threatened with physical violence in the workplace. Safran and Tartaglini (1996) have indicated that almost half of all the employees 
of the American penitentiary system claim to have been the subject of at least one attack by a prisoner which entailed injuries.

While men, on average, are more affected by physical violence than women (Warchol, 1998), distinct differences exist between the two sexes concerning the professional field and the type of violence. Women who work in the field of education and in the penitentiary system are more often victims of violent acts than men (Fischer and Gunnison, 2001). Men are more often victims of serious injuries while women are more often victims of sexual violence and rape (Craven, 1997; Crowell and Burgess, 1996).

The admissions and self-reports of the actors of physical violence are rare. Only 1 to $2 \%$ of the employees have admitted to committing an act of physical aggression (Boye and Wasserman, 1996; Slora, 1991). Nevertheless, Latham and Perlow (1996) have shown that, during the year in which they studied a population of health care professionals in psychiatry, $12 \%$ of them were dismissed for having subjected the patients to violent treatment.

\section{Causes of physical violence}

Four groups of causes in the manifestation of physical violence are generally distinguished (Einarsen, 1999; Zapf, 2004):

1 causes linked to the institution itself (its management, internal work organization);

2 causes linked to the aggressor;

3 causes linked to victim himself (personality);

4 and causes linked to the social group and the community (group pressure).

We will not consider here the explicit differentiation of the forms of physical violence concerning the relation which exists between the aggressor and the organization (cf. chapter on definitions; Braverman, 1999). The empirical data currently available is reported for the majority of the cases of type 3 causes of violence (between co-workers).

\subsection{Causes linked to the organization}

The structure of the organization (that is, the degree of complexity), of bureaucratization or of centralization or of the social structure which can provoke the manifestation of violence (Tobin, 2001), the climate or the culture of the organization have been studied in order to explain violence (Sperry, 1998).

The absence of social support on the part of hierarchical supervisors as well as co-workers increases the risk of being subject to physical threats in the workplace (Cole et al., 1997). Likewise, the stress linked to work (Barling, 1996; Warshaw and Messite, 1996) as well as the perception of injustice (Folger and Baron, 1996; Baron et al., 1999; Glomb, 2002; Kennedy et al., 2004) have been shown to be organizational factors in relation to the manifestation of violence in the workplace.

The role of uncertainty concerning job stability represents a causal factor which is currently under debate. While Barling
(1996) has shown a relationship between a lack of job security and aggressive behaviors, Greenberg and Barling (1999) were not able to confirm this relation.

However a large number of results exist concerning the influence of the layout/nature of the work station. Thus, in the context of security guards or transporters of funds, the acts of violence on the part of clients are more frequent when there are individual job stations (Castillo and Jenkins, 1994; Kraus, 1987).

\subsection{Causes linked to the aggressor}

The overall relationship between the consumption of alcohol and aggressive behavior is well-known. It has been widely documented by research in general (Krahé, 2001) and also more particularly concerning physical violence in the workplace (Bennett and Lehman, 1996; Greenberg and Barling, 1999; Gustafson, 1991; Warshaw and Messite, 1996).

Victimization experienced in the past - during childhood or in the professional environment - are also important predictors of violent behaviors towards co-workers and supervisors (Greenberg and Barling, 1999; Jockin et al., 2001; Douglas and Martinko, 2001).

Numerous personality factors have been studied in relation to violence. Thus, low self-esteem (Barling, 1996), irritability (Caprara et al., 1994), insufficient control of impulsions (Hynan and Grush, 1986), pronounced Type A behavior (Baron et al., 1999) as well as a strong tendency to become annoyed - particularly when it is combined with weak self-control (Allcorn, 1994; Douglas and Martinko, 2001) - have been proven to be particularly important predictors of violent behaviors in the professional environment (Hepworth and Towler, 2004).

\subsection{Causes linked to the victim}

A high level of alcohol consumption by the victim also increases his risk of victimization (McFarlin et al., 2001). Moreover, recent studies lead one to assume that the individuals who present burnout symptoms would also be more prone to threats and physical violence in the workplace (Winstanley and Whittington, 2002).

Finally, the absence of strategies adapted to resolve conflicts constitutes an important risk factor, particularly concerning individuals who occupy a lower level in the hierarchy of an enterprise (Aquino, 2000) and have a low self-image (Harvey and Keashley, 2003).

\subsection{Causes linked to the society}

In particular, changes in the job station as well as in the environment or the social status which result from them can lead to greater aggressiveness among employees (Baron and Neumann, 1996). In a global approach to society, Elliot and Jarrett (1994) refer to the potential role played by the economic climate and multicultural situations.

In modeling the structure of regressive reaction, Neuman and Baron (1998) identify the principal factors which condition 


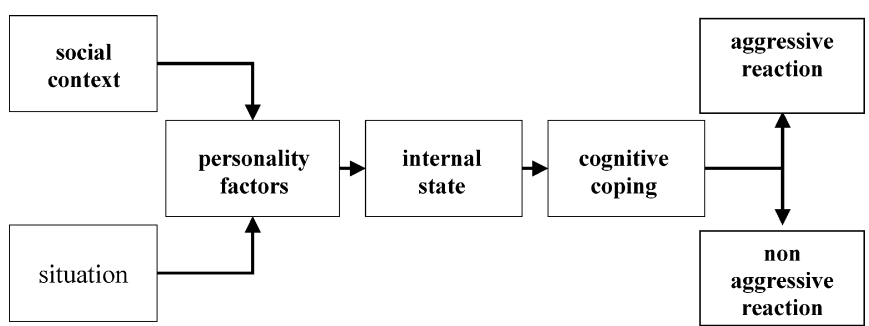

Fig. 1. Theoretical model of aggression in the workplace by Neuman and Baron (1998).

aggression in the workplace and show the theoretical relationship between them. In addition to social determinants (unfair treatment, frustration, increase in the diversity of work tasks, normative behavior and transgressing the norms), situational factors (changes in the work station, environmental constraints such as heat, noise, etc.) which, when associated with certain personality factors (Type A behavior, self-monitoring and hostile attribution bias) are likely to provoke a state of unpleasant feelings. Following cognitive coping strategies, this state of unpleasant feelings and hostile thoughts (internal state) hypothetically results in behaviors which are either aggressive or non aggressive (Fig. 1).

Baron et al. have conducted research to validate their model. They have shown, in particular, that a change in the organization of work, the perception of injustice, as well as Type A behavior can lead to significantly more frequent aggressive behaviors in the workplace (Baron and Neumann, 1996; Baron et al., 1999).

\section{Consequences of violence}

The consequences of physical violence prove to be extremely diverse. In addition to direct consequences, a multitude of other so-called indirect consequences are reported (Barling, 1996). The difference between the consequences concerning the organization, individual consequences and social consequences can be made on this subject (Hoel et al., 2001). Effects on health can be found on each level.

\subsection{Consequences concerning the organization}

The after-effects of physical violence are manifested both on the level of the productivity and the competitiveness of the enterprise, for example, by an increase in absenteeism (Southerland et al., 1997; Warshaw and Messite, 1996). The extent of the economic prejudice to organizations caused by acts of violence is difficult to evaluate. While direct economic and material prejudice can be calculated (Walter, 1993), it is hardly possible to anticipate it and hence neither to calculate all of the long-term and indirect effects on the organization, nor to anticipate all of the psychological and health-related consequences that a violent act will have on the individual concerned (Brakel, 1998; Elliot and Jarrett, 1994). The costs following a reduction in productivity due to psychological traumas, which still persist, can be considerable (Jenkins et al., 1992).

The process of recovering one's psychological equilibrium in the workplace or one's capacity to work can lead to a decrease in the commitment to the enterprise (Rogers and Kelloway, 1997; Schat and Kelloway, 2000), by a withdrawal from activities unrelated to professional activities (Barling et al., 2001; Mantell and Albrecht, 1994), by dissatisfaction concerning one's job (Budd et al., 1996; Discroll et al., 1995) or even by the search for a new job or a new work station (LeBlanc and Kelloway, 2002).

\subsection{Individual consequences}

In addition to concrete physical injuries, psychosocial consequences are particularly observed among victims of physical violence (Greve, 2002; Ruback and Thompson, 2001). Exaggerated reactions to stress and especially the fear of enduring other attacks (Barling et al., 2001; Rogers and Kelloway, 1997) often lead to health problems (depression, psychosomatic disorders) among victims of physical violence (Budd et al., 1996; Hoel et al., 2001; Hurrell et al., 1996).

In 10 to $18 \%$ of cases, victims will develop symptoms which meet the criteria of Posttraumatic Stress Disorder (PTSD; Flannery, 1995; Warshaw and Messite, 1996; Teegen, 2002). PTSD is defined by the simultaneous presence of symptoms belonging to three distinct groups of symptoms (ICD-10, 1994):

- avoidance symptoms:

○ avoiding situations, activities, thoughts and feelings linked to the experienced traumatic event,

- a state of emotional inflexibility or deafness,

- a limited affective scope;

- intrusions:

- painful memories concerning the traumatic event which frequently fill one's thoughts,

o nerve-racking dreams or nightmares,

- flashbacks;

- hyperactivation:

○ impossibility to relax, sleep problems, concentration and memory problems,

$\circ$ fear and irritability;

- moreover, a loss of interest in activities done beforehand, feelings of guilt or physiological reactions (heart palpitations, high anxiety) can appear.

PTSD often appears with associated disorders (comorbidity): anxiety, depression, somatic problems, personality disorders (Deering et al., 1996; Maercker, 2003) or suicidal tendencies. It has also been shown that the individuals concerned show a higher rate of professional problems caused by the damage linked to the symptoms themselves (irritability, avoidance behaviors, etc, Barling, 1996; Maercker, 1998). The reduction in concentration and self-esteem, as well as social withdrawal, particularly have a negative effect concerning work (Brady, 1999). Posttraumatic reactions as well as negative effects concerning work have been observed among bank employees who were victims of a holdup as well as among workers in other areas (De Boer et al., 1999; Miller-Burke et al., 1999; Tarquinio et al., 2004b). 


\subsection{Social consequences}

In addition to the costs to the organization, the costs to the society must also be mentioned. The excess spending by the health system and/or the social system caused by long-term treatments of traumas as well as work absenteeism for long periods or early retirement can be considerable (Barling, 1996; Chappell and DiMartino, 2000). Regarding traumatic experiences, we must point out that it is not only the victims, but also the witnesses of violent acts who react with similar symptoms and who should be treated (Rogers and Kelloway, 1997; Leather et al., 1998).

On the level of social interactions, inappropriate reactions on the part of the victim's family and friends in particular (manifested distress, inadequate help, isolating the victim) can lead to a secondary victimization (Montada, 1988).

\section{Concepts and preventive measures}

The interventions and the strategies at issue in the context of the prevention of physical violence in the workplace are destined to prevent the manifestation of violent acts as well as to minimize the negative consequences. The measures can be differentiated depending upon the exact moment when they are implemented as well as the field or target group which they aim at. The measures prior to the incident are destined to prevent the recurrence of the violent act. Peek-Asa et al. (2004) have shown that with their "workplace violence prevention programme", consisting of individual consultations, brochures and a video, the frequency of violence could be significantly reduced. The aim of some of the counseling sessions search for preventing injuries during an attack. Finally, counseling how to manage situations following violence aims to minimize the damage caused by this violence (Runyan et al., 2000). The areas targeted by this counseling deal with both the reorganization of the physical environment and decision making on the management level of an organization, or even change on the level of its members' behavior.

\subsection{Measures concerning the physical environment}

In addition to punctual measures destined to optimize security (Flannery, 1995), the Crime Prevention Through Environmental Design (CPTED) program has been implemented particularly in the retail business. This program is destined to reduce the occurrence of attacks by architectonic changes in the work environment. Based on an analysis of 26 evaluation studies of the CPTED, Casteel and Peek-Asa (2000) have shown that the use of this vast program of prevention (which takes into account surveillance of the work station, the itinerary to get there, the choice of the location of the activity, the organization of the work station, etc) reduces the number of attacks by between 12 and 65\% (Peek-Asa et al., 2001).

\subsection{Measures concerning the management of an organization and the behavior of members of an organization}

The target group of the intervention can be either the aggressor, the victim, the social circle or the organization (Runyan et al., 2000). Four different starting points in preventive interventions linked to the organization, which are carried out in the workplace, are distinguished:

- measures taken in the context of hiring personnel;

- measures concerning company policy and the climate of the organization;

- tips and training sessions for the employees and the supervisors;

- and lay-offs or dismissing employees (cf. Howard, 2001; Neuman and Baron, 1998; Chappell and DiMartino, 2000).

\subsubsection{Measures in the context of hiring personnel}

This step includes different procedures which permit the identification of a potential aggressor before he enters an enterprise. However, job application forms are rarely instructive or revealing in this respect (Howard, 2001). Moreover, filtering out potential aggressors using a questioning technique alone proves to be difficult (Atkinson, 2001; Lanyon and Goodstein, 2004; Slora et al., 1991).

\subsubsection{Company policy and procedure in case of violence}

The principal aim here is to create an organizational climate to prevent violence. This can be made possible by determining a unanimous position of the enterprise against all acts of violence, as well as by the existence of a clear interior regulation which provides the application of sanctions in case of fault. As examples, we note the famous policy of "zero tolerance", the recognized procedures to be applied in case of incorrect behavior, the posting of easily understood disciplinary sanctions, the existence of a procedure for dealing with complaints or rules of behavior.

Moreover, unsparing organizational support following a violent event can reduce the negative consequences on the social climate and on the functioning of the enterprise (Schat and Kelloway, 2003).

\subsubsection{Counseling and training measures for employees and management}

The measures in this area are based on the employee's capacity to recognize warning signals (Mantell and Albrecht, 1994) or to behave in an appropriate manner in violent situations. In this context, Grenyer et al. (2004) have positively evaluated a program in which the supervisors learn how to deal with violent situations. Kinney (1996) has developed a training program to recognize threatening situations. Breakwell (1998) shows different methods for behaving when faced with external violence on the part of employees.

Moreover, different training for communication and stress management are proposed in an attempt to manage trying and conflict situations (Flannery, 1995). Thus, programs which aim 
at learning to control one's emotions and anger have been proposed in order to help potential authors of violent acts manage threatening situations (Allcorn, 1994; Schwenkmezger et al., 1999). In the framework of the Employee Assistance Programs (EAPs), employees are offered the possibility of being aided by professional councilors in order to find solutions for conflicts.

Furthermore, different programs, with the aim of preventing the development of posttraumatic stress syndrome among victims of violent acts, have been evaluated. Flannery et al. (1995) tested the Assaulted Staff Action Program (ASAP) on hospital personnel. This program of crisis intervention is created with the employees in order to elaborate measures that reduce posttraumatic effects. A certain number of employees thus learn how to carry out a debriefing and to propose help to victims of violent acts within $20 \mathrm{~min}$ of the event. The authors of the program have shown that its use has produced a positive effect in relation to maintaining job efficiency and helps to reduce violent acts in the hospital (Flannery et al., 1996; Flannery, 2000). Another program was used by Steffgen et al. (2002) for the prevention of posttraumatic stress syndrome among bank employees after a holdup. The program essentially proposes diagnostic screening and offers psychological counseling derived from the principles of cognitive-behavioral therapy. It is based on the Critical Incident Stress Debriefing Programme - CISD by Mitchell (1983) and the crisis intervention program by Manton and Talbot (1990). The participants in the training program reported a significant reduction in the symptoms of PTSD in comparison to a control group (Tarquinio et al., 2004b).

\subsubsection{Laying-off/dismissing an employee}

Acts of violence often occur in situations of rescinding a job contract, in dismissals, or when there is change due to delocalization of the company. The feeling of injustice, which is likely to entail violent reactions, could be reduced by offering an "outplacement" service.

Taking into account the complexity of the problem, the organizations show a preference for programs with multiple components (Warshaw and Messite, 1996). The United States Postal Services has therefore developed a program to prevent violence which combines measures in the context of hiring personnel (through screenings and hiring tests), security, company policy, the climate of the organization, the support offered to employees and by dismissing violent employees (Anfuso, 1994; Kurutz et al., 1996). Mantell and Albrecht (1994) has developed a similar program in which seven stages are distinguished:

- screening;

- perceiving signs of risk;

- rules of behavior;

- behavioral training;

- counseling, coaching;

- optimization of security measures;

- follow-ups.

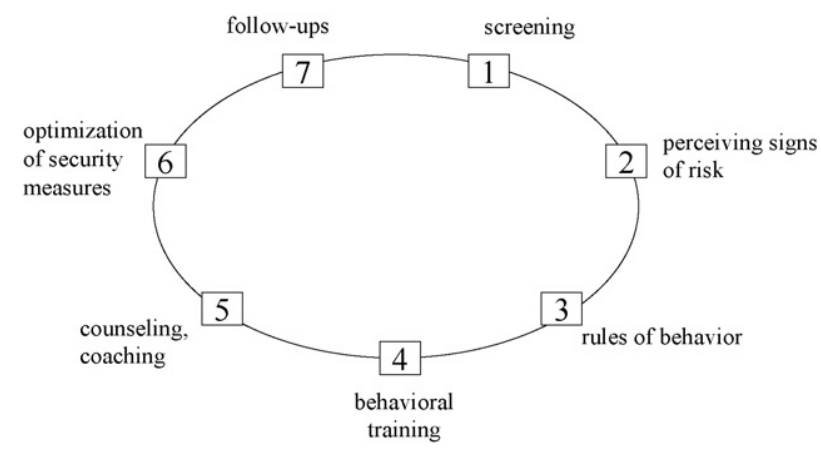

Fig. 2. Seven stages for preventing violence in the workplace by Mantell and Albrecht (1994).

These elements are then combined in function of the needs anticipated for the prevention of violence (Fig. 2).

Cox and Leather (1994) consider the implication of the entire organization to be indispensable in the prevention of violence. Nicoletti and Spooner (1996) have developed a three-phase model with this goal in mind. During the first phase, the organization is asked to document and eventually take into account all of the imaginable measures and actions to prevent violence, particularly in the context of hiring or firing an employee. In the second phase, the employees are trained to appropriately manage threatening or violent situations. Finally, during the third phase, they are taught the procedures to follow when a violent act has been committed.

\section{Conclusion}

Very little research has been done to date on the evaluation and the comparative evaluation of the different programs or measures of prevention proposed. Initially, it seems that the measures centered on the organization and programs with multiple components are more promising than the measures centered on the individual and programs with a single component (Runyan et al., 2000). In any event, it appears necessary to extend research on the evaluation of these programs (Farrell and Cubit, 2005).

It must be noted that only a small percentage $(8.8 \%)$ of enterprises claim to follow strategies for the prevention of physical violence. Most organizations take measures only after a violent incident (Howard, 2001). The measures most often used include screening in the context of hiring procedures, Employee Assistance Programs as well as hiring security guards (Bush and O'Shea, 1996). Nevertheless, an enterprise's interest in acting preventively against the occurrence of violence can be activated or increased by legal measures (Barish, 2001; Chappell and DiMartino, 2000).

Finally, the lack of exchange between researchers who are insufficiently aware of the results and developments of their colleagues' research on the prevention of violence in sectors or areas which are different from their own is regrettable. Thus, for example, part of the research on school violence is of certain potential interest for research on violence in the workplace (Steffgen, in press). 


\section{The Six-Strategy USPS Violence Prevention Program.}

The United States Postal Service (USPS) has developed a six-strategy model that is designed to access and engage all of the major resources within the Postal Service related to violence prevention. The model focuses on prevention and early intervention. The strategies include:

1. Selection. The goal of this strategy is to ensure that the USPS employs the right persons.

2. Security. Both security teams as Postal facilities and law enforcement professionals from the Inspection service and Postal Police play critical roles in prevention and intervention.

3. Policy. The Postal Service, its unions and management associations authored a joint statement on violence in the workplace that includes an unequivocal commitment to "do everything within our power to prevent further incidents of workrelated violence". The joint statement also affirms the right of all employees to a "safe and humane working environment".

4. Climate. The Employee Assistance Program (EAP) is involved particularly with organizational development interventions that are designed to ensure a safe and healthful workplace and positive corporate culture.

5. Employee support. The EAP is committed to early identification and prompt intervention, allowing problems to be dealt with before they escalate to the point to loss of behavioral control.

6. Separation. The USPS is actively involved in the refinement of procedures designed to make the termination process safer and more effective. The EAP becomes actively involved if an individual being terminated requires support and assistance, or if he or she may represent a potential threat to self, other individuals, or the organization.

(Kurutz, Johnson \& Sugden, 1996, p. 348 ff).

\section{References}

Allcorn, S., 1994. Anger in the Workplace: Understanding the Causes of Aggression and Violence. Quorum Books, Westport, CT.

Anfuso, D., 1994. Workplace violence. Personnel Journal 73, 66-77.

Aquino, K., 2000. Structural and individual determinants of workplace victimization: the effects of hierarchical status and conflict management style. Journal of Management 26 (2), 171-193.

Arnetz, J.E., 1998. The Violent Incident Form (VIF): a practical instrument for the registration of violent incidents in the health care workplace. Work and Stress 12 (1), 17-28.
Arnetz, J.E., Arnetz, B.B., Petterson, I.L., 1996. Violence in the nursing profession: occupational and lifestyle risk factors in Swedish nurses. Work and Stress 10 (2), 119-127.

Atkinson, W., 2001. Keeping violent employees out of the workplace. Risk Management 48, 12-21.

Barish, R.C., 2001. Legislation and regulations addressing workplace violence in the United States and British Columbia. American Journal of Preventive Medicine 20 (2), 149-154.

Barling, J., 1996. The prediction, experience and consequences of workplace violence. In: VandenBos, G.R., Bulatao, E.Q. (Eds.), Violence on the Job. Identifying Risks and Developing Solutions. American Psychological Association, Washington, D.C, pp. 29-49.

Barling, J., Rogers, A.G., Kelloway, E.K., 2001. Behind closed doors: in-home workers' experience of sexual harassment and workplace violence. Journal of Occupational Health Psychology 6, 255-269.

Baron, R.A., Neumann, J.H., 1996. Workplace violence and workplace aggression: evidence on their relative frequency and potential causes. Aggressive Behavior 22 (3), 161-173.

Baron, R.A., Neumann, J.H., 1998. Workplace aggression: the iceberg beneath the tip of workplace violence: evidence on its forms, frequency and potential causes. Public Administration Quarterly 21, 446-464.

Baron, R.A., Neuman, J.H., Geddes, D., 1999. Social and personal determinants of workplace aggression: evidence for the impact of perceived injustice and the Type A behavior pattern. Aggressive Behavior 25 (4), 281-296.

Baron, R.A., Richardson, D.R., 1994. Human Aggression, 2nd Edn. Plenum, New York.

Beale, D., Cox, T., Leather, P., 1996. Work-related violence - is national reporting good enough? Work and Stress 10 (2), 99-103.

Bennett, J.B., Lehman, W.E., 1996. Alcohol, antagonism and witnessing in the workplace: drinking climates and social alienation-integration. In: VandenBos, G.R., Bulatao, E.Q. (Eds.), Violence on the Job. Identifying Risks and Developing Solutions. American Psychiatric Association, Washington DC, pp. 105-152.

Berkowitz, L., 1993. Aggression. Its causes, Consequences and Control. McGraw-Hill, New York.

Bierhoff, H.W., Wagner, U., (Hrsg.) 1998. Aggression und Gewalt. Phänomene. In: Ursachen und Interventionen. Kohlhammer, Stuttgart.

Bornewasser, M., 1998. Soziale Konstruktion von Gewalt und Aggression. In: Bierhoff, H.W., Wagner, U. (Eds.), Aggression und Gewalt. Phänomene, Ursachen und Interventionen. Kohlhammer, Stuttgart, pp. 48-62.

Boye, M.W., Wasserman, A.R., 1996. Predicting counterproductivity among drug store applicants. Journal of Business and Psychology 10, 337-349.

Brady, C., 1999. Surviving the incident. In: Leather, P., Brady, C., Lawrence, C., Beale, D., Cox, T. (Eds.), Work-related Violence: Assessment and Intervention. Routledge, London, pp. 52-68.

Brakel, S.J., 1998. Legal liability and workplace violence. Journal of the American Academy of Psychiatry and the Law 26, 553-562.

Braverman, M., 1999. Preventing Workplace Violence: a Guide for Employers and Practitioners. Sage, Thousand Oaks, CA.

Breakwell, G.M., 1998. Aggression bewältigen. Huber, Bern.

Budd, J.W., Arvey, R.D., Lawless, P., 1996. Correlates and consequences of workplace violence. Journal of Occupational Health Psychology 1, 197-210.

Bulatao, E.Q., VandenBos, G.R., 1996. Workplace violence: its scope and the issues. In: VandenBos, G.R., Bulatao, E.Q. (Eds.), Violence on the Job. Identifying Risks and Developing Solutions. American Psychiatric Association, Washington DC, pp. 1-23.

Bush, D.F., O'Shea, P.G., 1996. Workplace violence: comparative use of prevention practices and policies. In: VandenBos, G.R., Bulatao, E.Q. (Eds.), Violence on the Job. Identifying Risks and Developing Solutions. American Psychiatric Association, Washington DC, pp. 283-297.

Buss, A.H., 1961. The Psychology of Aggression. Wiley, New York.

Buss, A.H., Perry, M., 1992. The aggression questionnaire. Journal of Personality and Social Psychology 63 (3), 452-459.

Caprara, G.V., Barbaranelli, C., Pastorelli, C., Perugini, M., 1994. Individual differences in the study of human aggression. Aggressive Behavior 20, 291-303. 
Casteel, C., Peek-Asa, C., 2000. Effectiveness of Crime Prevention Through Environmental Design (CPTED) in reducing robberies. American Journal of Preventive Medicine 18 (4), 99-115.

Castillo, D.N., Jenkins, E.L., 1994. Industries and occupations at high risk for work-related homicide. Journal of Occupational Medicine 36, 125-132.

Chappell, D., DiMartino, V., 2000. Violence at Work. International Labour Office, Geneva.

Cole, L.L., Grubb, P.L., Sauter, S.L., Swanson, N.G., Lawless, P., 1997. Psychosocial correlates of harassment, threats and fear of violence in the workplace. Scandinavian Journal of Work, Environment and Health 13 (6), 450-457.

Collins, J., Cox, B., Langan, P., 1987. Job activities and personal crime victimization: implications for theory. Social Science Research 16, 345-360.

Cox, T., Leather, P., 1994. The prevention of violence at work: Applications of a cognitive behavioral theory. In: Cooper, C.L., Robertson, I.T. (Eds.), International review of industrial and organiziational psychology. Wiley, Chichester, England, pp. 213-245.

Craven, D., 1997. Sex Differences in Violent Victimization, 1994. Bureau of Justice Statistics, Washington, DC.

Crowell, N., Burgess, A., 1996. Understanding Violence Against Women. National Academy Press, Washington, DC.

De Boer, C., Steffgen, G., Bollendorff, C., 1999. Diagnose der Posttraumatischen Belastungsstörung bei Bankangestellten nach einem Überfall. Arbeitsmedizin, Sozialmedizin, Umweltmedizin 34, 315-319.

Deering, C.G., Glover, S.G., Ready, D., Eddleman, H.C., Alarcon, R.D., 1996. Unique patterns of comorbidity in posttraumatic stress disorder from different sources of trauma. Comprehensive Psychiatry 37, 336-346.

Discroll, R.J., Whorthington, K.A., Hurrell Jr., J., 1995. Workplace assault: an emerging job stressor. Consulting Psychology Journal: Practice and Research 47 (4), 205-211.

Douglas, S.C., Martinko, M.J., 2001. Exploring the role of individual differences in the prediction of workplace aggression. Journal of Applied Psychology 86 (4), 547-559.

Einarsen, S., 1999. The nature and causes of bullying. International Journal of Manpower 20, 16-17.

Elliot, R.H., Jarrett, D.T., 1994. Violence in the workplace: the role of human resource management. Public Personnel Management 23, 287-299.

European Foundation for the Improvement of Living and Working Conditions (2000). Third European Survey on Working Conditions. European Foundation, Dublin.

Farrell, G., Cubit, K., 2005. Nurses under threat: a comparison of content of 28 aggression management programs. International Journal of Mental Health Nursing 14, 44-53.

Feshbach, S., 1964. The function of aggression and the regulation of aggressive drive. Psychological Review 71, 257-272.

Fischer, B., Gunnison, E., 2001. Violence in the workplace: gender similarities and differences. Journal of Criminal Justice 29 (2), 145-155.

Flannery, R.B., 1995. Violence in the Workplace. Crossroad, New York.

Flannery, R.B., 1996. Violence in the workplace. 1970-1995: a review of the literature. Aggression and Violent Behaviour 1 (1), 3-25.

Flannery, R.B., 2000. Post-incident crisis intervention: a risk management strategy for preventing workplace violence. Stress Medicine 16, 229-232.

Flannery, R.B., Penk, W.E., Hanson, M.A., Flannery, G.J., 1996. The Assaulted Staff Action Program: guidelines for fielding a team. In: VandenBos, G.R., Bulatao, E.Q. (Eds.), Violence on the Job. Identifying Risks and Developing Solutions. American Psychiatric Association, Washington, DC, pp. 327-341.

Flannery Jr., R.B., Hanson, M.A., Penk, W., Flannery, G., Gallagher, C., 1995. The Assaulted Staff Action Program: an approach to coping with the aftermath of violence in the workplace. In: Murphy, L.R., Hurrell J.Jr., Sauter, S.L., Puryear Keita, G. (Eds.), Job Stress Interventions. American Psychological Association, Washington, DC, pp. 199-212.

Folger, R., Baron, R.A., 1996. Violence and hostility at work: a model of reactions to perceived injustice. In: VandenBos, G.R., Bulatao, E.Q. (Eds.), Violence on the Job: Identifying Risks and Developing Solutions. American Psychological Association, Washington, D.C, pp. 51-85.

Friedman, L.N., Brown Tucker, S., Neville, P.R., Imperial, M., 1996. The impact of domestic violence on the workplace. In: VandenBos, G.R., Bulatao, E.Q.
(Eds.), Violence on the Job. Identifying Risks and Developing Solutions. American Psychiatric Association, Washington, DC, pp. 153-161.

Galtung, J., 1975. Strukturelle Gewalt. Rowohlt, Reinbek.

Glomb, T.M., 2002. Workplace anger and aggression: informing conceptual models with data from specific encounters. Journal of Occupational Health 7 (1), 20-36.

Goodman, R.A., Jenkins, E.L., Mercy, J.A., 1994. Workplace-related homicide among health care workers in the United States, 1980 through 1990. Journal of the American Medical Association 272, 1686-1688.

Greenberg, L., Barling, J., 1999. Predicting employee aggression against coworkers, subordinates and supervisors: the roles of person behaviors and perceived factors. Journal of Organizational Behavior 20 (6), 897-913.

Grenyer, B., Ilkiw-Lavalle, O., Biro, P., Middleby-Clements, J., Cominos, A., Coleman, M., 2004. Safer at work: development and evaluation of an aggression and violence minimization program. Australian and New Zealand Journal of Psychiatry 38, 804-810.

Greve, W., 2002. Gesundheitliche Auswirkungen von Gewalt. In: Schwarzer, R., Jerusalem, M., Weber, H. (Eds.), Gesundheitspsychologie von A bis Z. Ein Handwörterbuch. Hogrefe, Göttingen, pp. 227-230.

Gustafson, R., 1991. Male physical aggression as a functional of alcohol frustration, and subjective mood. International Journal of Addictions 26, 255-266.

Guterman, N.B., Jayaratne, S., Gargal, D., 1996. Workplace violence and victimization experienced by social workers: a cross-national study of American and Israelis. In: VandenBos, G.R., Bulatao, E.Q. (Eds.), Violence on the Job. Identifying Risks and Developing Solutions. American Psychiatric Association, Washington DC, pp. 175-188.

Guy, J.D., Brown, C.K., Poelstra, P.L., 1990. Who gets attacked? A national survey of patient violence directed at psychologists in clinical practice. Professional Psychology. Research and Practice 21, 493-495.

Hampel, R., Selg, H., 1998. FAF: Fragebogen zur Erfassung von Aggresivitätsfaktoren. Hogrefe, Göttingen.

Harvey, S., Keashley, L., 2003. Predicting the risk for aggression in the workplace: risk factors, self-esteem and time at work. Social Behavior and Personality $31,807-814$

Hashemi, L., Webster, B.S., 1998. Non-fatal workplace violence worker's compensation claims (1993-1996). Journal of Occupational Environment Mecicine 40, 561-567.

Hepworth, W., Towler, A., 2004. The effects of individual differences and charismatic leadership on workplace aggression. Journal of Occupational Health Psychology 9, 176-185.

Hoad, C.D., 1993. Violence at work: perspectives from research among 20 British employers. Security Journal 4, 64-86.

Hoel, H., Sparks, K., Cooper, C.L., 2001. The Cost of Violence/Stress at Work and the Benefits of a Violence/Stress-Free Working Environment. International Labour Organisation, Geneva.

Howard, J.L., 2001. Workplace violence in organizations: an exploratory study of organizational prevention techniques. Employee Responsibilities and Rights Journal 3 (2), 57-75.

Hurrell, J.J., Worthington, K.A., Driscoll, R.J., 1996. Job stress, gender and workplace violence: analysis of assault experiences of state employees. In: VandenBos, G.R., Bulatao, E.Q. (Eds.), Violence on the Job. Identifying Risks and Developing Solutions. American Psychiatric Association, Washington DC, pp. 163-170.

Hynan, D.J., Grush, J.E., 1986. Effects of impulsivity, depression, provocation and time on aggression behavior. Journal of Research in Personality 20, $158-171$.

Jayaratne, S., Vinokur-Kaplan, D., Nagda, B.A., Chess, W.A., 1996. A national study on violence and harassment of social workers by clients. Journal of Applied Social Sciences 20 (1), 1-14.

Jenkins, E.L., 1996. Workplace homicide: industries and occupations at high risk. Occupational Medicine State of Art Reviews 11 (2), 219-225.

Jenkins, E.L., Layne, L.A., Kisner, S.M., 1992. Homicide in the workplace: the U.S. experience, 1980-1988. AAOHN Journal 40, 215-218.

Jockin, V., Arvey, R., McGue, M., 2001. Perceived victimization moderates selfreports of workplace aggression and conflict. Journal of Applied Psychology $86,1262-1269$. 
Kennedy, D., Homant, R., Homant, M., 2004. Perception of injustice as a predictor of support for workplace aggression. Journal of Business and Psychology 18, 323-336.

Kinney, J.A., 1996. The dynamics of threat management. In: VandenBos, G.R., Bulatao, E.Q. (Eds.), Violence on the Job. Identifying Risks and Developing Solutions. American Psychiatric Association, Washington DC, pp. 299-313.

Krahé, B., 2001. The Social Psychology of Aggression. Psychology Press, Hove.

Kraus, J.F., 1987. Homicide while at work: persons, industries and occupations at high risk. American Journal of Public Health 77, 1285-1289.

Kurutz, J.G., Johnson, D.L., Sugden, B.W., 1996. The United States Postal Services Employee Assistance Program: a multifaceted approach to workplace violence prevention. In: VandenBos, G.R., Bulatao, E.Q. (Eds.), Violence on the Job. Identifying Risks and Developing Solutions. American Psychiatric Association, Washington DC, pp. 343-352.

Lanyon, R., Goodstein, L., 2004. Validity and reliability of a pre-employment screening test: the Counterproductive Behavior Index (CBI). Journal of Business and Psychology 18, 533-553.

Lanza, M.L., 1996. Violence against nurses in hospitals. In: VandenBos, G.R., Bulatao, E.Q. (Eds.), Violence on the Job. Identifying Risks and Developing Solutions. American Psychiatric Association, Washington DC, pp. 189-198.

Latham, L.L., Perlow, R., 1996. The relationship of client-directed aggressive and nonclient-directed aggressive work behavior with self-control. Journal of Applied Social Psychology 26, 1027-1041.

Leather, P., Lawrence, C., Beale, D., Cox, T., Dickson, R., 1998. Exposure to occupational violence and the buffering effects of intra-organizational support. Work and Stress 12, 161-178.

LeBlanc, M.M., Kelloway, E.K., 2002. Predictors and outcomes of workplace violence and aggression. Journal of Applied Psychology 87, 444-453.

Leonard, J.R., Sloboda, B.A., 1996. Workplace Violence: a Review of Current Literature. Paper Presented at the Annual Meeting of the Society for Industrial and Organizational Psychology. CA, San Diego.

Lusk, S.L., 1992. Violence in the workplace. American Association of Occupational Health Nurses Journal 40, 212-213.

Maercker, A., 1998. Posttraumatische Belastungsstörungen: psychologie der Extrembelastungsfolgen bei Opfern politischer Gewalt. Pabst, Lengerich.

Maercker, A., 2003. Posttraumatische Belastungsstörungen. In: Jerusalem, M., Weber, H. (Eds.), Psychologische Gesundheitsförderung. Diagnostik und Prävention. Hogrefe, Göttingen, pp. 635-654.

Mantell, M., Albrecht, S., 1994. Ticking Bombs. Defusing Violence in the Workplace. IRWIN Professional Publishing, New York.

Manton, M., Talbot, A., 1990. Crisis intervention after an armed hold-up: guidelines for counsellors. Journal of Traumatic Stress 3, 507-522.

McFarlin, S.K., Fals-Steward, W., Major, D.A., Justice, E.M., 2001. Alcohol use and workplace aggression: an examination of perpetration and victimization. Journal of Substance Abuse 13 (3), 303-321.

Miller-Burke, J., Attridge, M., Fass, P.M., 1999. Impact of traumatic events and organizational response: a study of bank robberies. Journal of Occupational Environment Medicine 41, 73-83.

Mitchell, J., 1983. When disaster strikes. The critical incidence stress debriefing process. Journal of Emergency Medical Services 8, 36-39.

Montada, L., 1988. Bewältigung von Schicksalsschlägen - Erlebte Ungerechtigkeit und wahrgenommene Verantwortlichkeit. Schweizerische Zeitschrift für Psychologie 47, 203-216.

Neuman, J.H., Baron, R.A., 1998. Workplace violence and aggression: evidence concerning specific forms, potential causes, and preferred targets. Journal of Management: Special issue: Yearly Review of Management 24 (3), 391-419.

Nicoletti, J., Spooner, K., 1996. Violence in the workplace: response and intervention strategies. In: VandenBos, G.R., Bulatao, E.Q. (Eds.), Violence on the Job. Identifying Risks and Developing Solutions. American Psychiatric Association, Washington DC, pp. 267-282.

O'Leary-Kelly, A.M., Griffin, R.W., Glew, D.J., 1996. Organizational-motivated aggression: a research framework. Academy of Management Review 21, 225-253.

Peek-Asa, C., Casteel, C., Mineschian, L., Erickson, R., Kraus, J., 2004. Compliance to a workplace violence prevention program in small business. American Journal of Preventive Medicine 26, 276-283.
Peek-Asa, C., Howard, J., Vargas, I., Kraus, J.F., 1997. Incidence of non-fatal workplace assault injuries determined from employers reports in California. Journal of Occupational Environment Medicine 39, 40-50.

Peek-Asa, C., Runyan, C.W., Zwerling, C., 2001. The role of surveillance and evaluation research in the reduction of violence against workers. American Journal of Preventive Medicine 20 (2), 141-148.

Poster, E.C., Ryan, J., 1994. A multiregional study of nurses beliefs and attitudes about work safety and patient assault. Hospital and Community 45 , 1104-1108.

Rogers, K.A., Kelloway, E.K., 1997. Violence at work: personal and organizational outcomes. Journal of Occupational Health Psychology 2, 63-71.

Rosen, J., 2001. A labor perspective of workplace violence prevention: identifying research needs. American Journal of Preventive Medicine 20 (2), $161-168$

Ruback, R.B., Thompson, M.P., 2001. Social and Psychological Consequences of Violent Victimization. Sage, Thousand Oaks, CA.

Runyan, C.W., Zakocs, R.C., Zwerling, C., 2000. Administrative and behavioral interventions for workplace violence prevention. American Journal of Preventive Medicine 18, 116-127.

Rutter, A., Hine, D., 2005. Sex differences in workplace aggression: an investigation of moderation and mediation effects. Aggressive Behavior 31, 254-270.

Safran, D.A., Tartaglini, A.J., 1996. Workplace violence in an urban jail setting. In: VandenBos, G.R., Bulatao, E.Q. (Eds.), Violence on the Job. Identifying Risks and Developing Solutions. American Psychiatric Association, Washington DC, pp. 207-216.

Salminen, S., 1997. Violence in the workplaces in Finland. Journal of Safety Research 28 (3), 123-131.

Schat, A.C., Kelloway, E.K., 2000. The effects of perceived control on the outcomes of workplace aggression and violence. Journal of Occupational Health Psychology 5 (3), 386-402.

Schat, A.C., Kelloway, E.K., 2003. Reducing the adverse consequences of workplace aggression and violence: the buffering effects of organizational support. Journal of Occupational Health Psychology 8 (2), 110-122.

Schulte, J.M., Nolt, B.J., Williams, R.L., Spinks, C.L., Hellsten, J.J., 1998. Violence and threats of violence experienced by public health field-workers. Journal of the American Medical Association 280, 439-442.

Schwenkmezger, P., Steffgen, G., Dusi, D., 1999. Umgang mit Ärger. Hogrefe, Göttingen.

Scezsny, G., 2004. Sexuelle Belästigung. In: Steffgen, G. (Ed.), Betriebliche Gesundheitsförderung. Problemzentrierte psychologische interventionen. Hogrefe, Göttingen, pp. 131-148.

Skarpaas, I., Hetle, A. (1996). Vold og trustler mot helse og sosialarbeidere. En kartleggingsundersoekelse blant medlemmer i Fellseorganisasjonen for arnevernspedagoger, sosionomer og vernepleiere. Notat 1/96. Oslo: Arbeidsforsknings Instituttet.

Slora, K.B., 1991. An empirical approach to determining employee deviance bas rates. In: Jones, J.W. (Ed.), Preemployment Honesty Testing. Quorum Books, Westport, CT, pp. 21-38.

Slora, K.B., Joy, D.S., Jones, J.W., Terris, W., 1991. The prediction of on-the-job violence. In: Jones, J.W. (Ed.), Preemployment Honesty Testing. Quorum Books, Westport, CT, pp. 171-183.

Southerland, M.D., Collins, P.A., Scarborough, K.E., 1997. Workplace Violence. Anderson, Cincinnati.

Sperry, L., 1998. Organizations that foster inappropriate aggression. PsychiatricAnnals 28 (5), 279-284.

Standing, H., Nicolini, D., 1997. Review of Workplace Related Violence. Health and Safety Executive. HSMO, London.

Steffgen, G., de Boer, C., Bollendorff, C., 2002. Prävention der Posttraumatischen Belastungsstörung bei Bankangestellten nach einem Überfall. Arbeitsmedizin, Sozialmedizin, Umweltmedizin 37, 369-372.

Steffgen, G., 2004. Körperliche Gewalt. In: Steffgen, G. (Ed.), Betriebliche Gesundheitsförderung. Problemzentrierte psychologische Interventionen. Hogrefe, Göttingen, pp. 149-170.

Steffgen, G. (in press). Violence in Luxembourg schools: the role of schoo culture. In: Österman, K., Björkqvist K. (Eds.), Contemporary research on aggression, vol. I: School violence. Abo Akademi University, Finland. 
Sullivan, C., Yuan, C., 1995. Workplace assaults on minority health and mental health care workers in Los Angeles. American Journal of Public Health 85, 1011-1014.

Tarquinio, C., Duveau, A., Tragno, M., Fischer, G.N., 2004a. La violence au travail. Un concept à l'étude pour un état des lieux. Revue Francophone du Stress et du Trauma 4, 137-146.

Tarquinio, C., Steffes, C., Tarquinio, P., Fayard, A., Tragno, M., Duveau, A., 2004b. Prise en charge psychologique de salariés victimes de hold-up. Revue Francophone du Stress et du Trauma 4, 195-202.

Teegen, F., 2002. Posttraumatische Belastungsstörungen bei gefährdeten Berufsgruppen. Huber, Bern.

Tobin, T.J., 2001. Organizational determinants of violence in the workplace. Aggression and Violent Behavior 6 (1), 91-102.

Tragno, M., Duveau, A., Tarquinio, C., 2007. Les violences et agressions physiques au travail: revue de questions. Revue Européenne de Psychologie Appliquée/European Review of Applied Psychology 57 (4), 237-255.

VandenBos, G.R., Bulatao, E.Q. (Eds.), 1996. Violence on the Job. Identifying Risks and Developing Solutions. American Psychological Association, Washington, D.C.

Violanti, J.M., 1996. Violence turned inward: police suicide in the workplace. In: VandenBos, G.R., Bulatao, E.Q. (Eds.), Violence on the Job. Identifying Risks and Developing Solutions. American Psychiatric Association, Washington DC, pp. 229-249.
Watson, A.L., Williams, J.E., Ball, A., 2001. Workplace violence: another face of the crisis. In: Sandhu, D.S. (Ed.), Faces of Violence: Psychological Correlates, Concepts, and Intervention Strategies. Nova Science Publishers, New York, US, pp. 3-21.

Walter, H., 1993. Mobbing - Kleinkrieg am Arbeitsplatz. Campus, Frankfurt/M. Warchol, G., 1998. Workplace Violence, 1992-1996. Bureau of Justice Statistics, Washington, DC.

Warshaw, L.J., Messite, J., 1996. Workplace violence: preventive and interventive strategies. Journal of Occupational and Environmental Medicine 38, 993-1006.

White, T.W., 1996. Research, practice and legal issues regarding workplace violence: a note of caution. In: VandenBos, G.R., Bulatao, E.Q. (Eds.), Violence on the Job. Identifying Risks and Developing Solutions. American Psychiatric Association, Washington DC, pp. 175-188.

Whittington, R.W., Shuttleworth, S., Hill, L., 1996. Violence to staff in a general hospital setting. Journal of Advanced Nursing 24, 326-387.

Winstanley, S., Whittington, R., 2002. Anxiety, burnout and coping styles in general hospital staff exposed to workplace aggression: a cyclical model of burnout and vulnerability to aggression. Work and Stress 16, 302-315.

Zapf, D., 2004. Mobbing. In: Steffgen, G. (Ed.), Betriebliche Gesundheitsförderung. Problemzentrierte psychologische Interventionen. Hogrefe, Göttingen, pp. 109-129. 